\title{
Examining Katakana Synform Errors Made by Japanese University Students
}

\author{
Raymond Stubbe and Kosuke Nakashima \\ Nagasaki University; Hiroshima Institute of Technology
}

\begin{abstract}
Laufer (1988) introduced the concept of synform errors, where second language (L2) learners confuse a word for a different but similar looking or sounding L2 word. Stubbe and Cochrane (2016) reported that of 1,187 commonly repeated errors on a Japanese to English non-contextual translation test, 461 were synform errors $(39 \%)$. This study introduces the concept of katakana consonant pairing synform errors, where Japanese learners of English can confuse one English word for another because some English consonants have no Japanese equivalent, for example, 1 and $\mathrm{v}$. Words containing these consonants can be transcribed into katakana using the closest Japanese consonant sound: $r$, $b$, respectively. This can result in katakana pairings (l-r, v-b), which may lead to confusion for the Japanese learners. "Vest" may be interpreted as "best," for instance. In the present study, English students at one Japanese university $(N=235)$ were given a Japanese to English non-contextual translation test containing the lower frequency member of 30 such katakana pairs ("vest" being a much less frequent word than its pair "best," for instance). Thirty words not having a katakana partner (e.g., shade) from the same JACET 8000 frequency levels were also tested. The study results suggest that katakana consonant pairing synform errors are problematic for these Japanese university students. Implications for the classroom and vocabulary assessment are presented.
\end{abstract}

Keywords: translation test; synform errors; katakana; Japanese EFL learners

\section{Introduction}

According to Batia Laufer (Laufer, Meara, \& Nation, 2005, p. 5), synforms "are word pairs or groups of words with similar (though not identical) sound, script, or morphology, which learners tend to confuse." Authors (2016) investigated commonly repeated errors that students made on an English to Japanese (L2 to L1) passive recall translation test of 40 high-frequency English words. Commonly repeated errors were defined as identical errors made by at least $10 \%$ of the testtakers. In that study, it was reported that "(s)ynform errors made up the largest category of errors, accounting for 461 (39\%) of the 1187 repeated errors" (Stubbe $\&$ Cochrane, 2016, p. 167). A large number of the commonly repeated synform errors resulted from katakana pairing, where two different English consonant-vowel combinations ( $\mathrm{r}-\mathrm{a}$ vs. 1-a, for instance) can be transcribed using one katakana symbol. This article will expand on the Authors' (2016) work by examining the 
possible causes of the common synform errors that Japanese learners make when completing a translation test.

\section{Background of the Study}

\subsection{Synform Errors}

"There is a wealth of evidence that L2 learners confuse words that sound and/or look alike" (Laufer, 1997, p. 146). As introduced by Laufer (1988), such confusions can be labeled synform errors, which she classified into 10 categories (see Appendix A). In categories 1-5, synforms are different from each other in an affix and identical in their root (e.g., fact-factor); while, categories 6-9 included synforms differing from each other in one phoneme, vowel, or consonant (flow-flaw). With the final category (number 10), synforms share identical consonants but differ in all or some of the vowels. Laufer (1988) tested English learners in Israel whose first languages were Arabic or Hebrew. Synform confusion errors can occur in words, in context, and in isolation, with both comprehension and production. They afflict L2 learners of all proficiency levels, ranging from young beginners through advanced adult students (Laufer, 1988). Other researchers have also considered synform errors in their classrooms and/or vocabulary studies. Nural (2014), examining intermediate-level Turkish learners of English, reported that synform errors appeared in a range of lesson activities, including reading, listening comprehension, vocabulary revision, and discussions. That study suggested that most of the synform errors resulted from synforms with the same root, but different suffixes. Kocic (2008), studying the effects of synforms on advanced-level Serbian learners of English, found that these learners also had difficulty with suffix-related synform errors. $\mathrm{Gu}$ and Leung (2002) stated that Chinese participants from both Beijing and Hong Kong "confused the form of the target word with the form of another English word already in their working vocabulary" (p. 131). Thus, it can be seen that synform errors occur with ESL learners across a wide variety of cultures and first languages.

\subsection{Katakana and Synform Errors}

Katakana, which is the syllabic portion of the Japanese writing system used for expressing words from other languages, can have a strong influence on second language learning. "When we consider orthographic similarities between English and Japanese, the visual overlap between the Roman alphabet and syllabic katakana is null" (Uchida 2007, p. 19). It is generally accepted that the Japanese language has no clear or transparent orthographic rules for transcribing English into katakana, which leads to inconsistencies in transcribing borrowed words. As explained by Bada (2001, p. 3):

The Japanese writing system is based on a syllabary rather than on a phonetic system ... It is based on five vowel sounds which occur with a number of consonants. Each vowel sound and its accompanying consonant has a separate symbol, termed kana [Katakana and Hiragana] ... the syllabic order in Japanese is generally consonant+vowel, or vowel alone. 
Katakana influence or interference with English pronunciation and readability has been studied by a number of researchers (Bada, 2001; Janjua, 2010; Nakao, 2013; Uchida, 2007). "According to the rules of katakana, most foreign words when borrowed into the Japanese language are transformed in a manner that makes them lose the pronunciation of their original language and instead acquire a uniquely Japanese way of pronunciation" (Janjua, 2010, p. 381). In Japanese, consonants must be followed by a vowel, except for "n" which can appear in syllabic final position. A further difference between the two languages is that a number of English consonants have no equivalent in Japanese: f, 1, and v, for example. These consonants are represented by the closest consonants $h, r$, and $b$, respectively. These f-h, l-r, and v-b pairings, which will be referred to as katakana pairings, can lead to confusion. To illustrate, the words "folk" and "fork" are both represented in Japanese with the same katakana symbols (フォーク; see Figure 1).

These katakana consonant pairings can lead to synform errors, where students see or hear one word in English and mistake it for the other word containing the other letter of the pair, "fair" versus "hair" or "rum" versus "run," for example. These katakana pairing errors are equivalent to Laufer's (1988, p. 128) Category 8: Synforms which differ from one another in one consonant classification. Two Japanese examples of such confusion are provided in Nakao (2013, p. 14), investigating student knowledge of various English loanwords in Japanese:

For example, two English words "glove" and "globe" are both represented as "guroobu” (グロブ) in Japanese, which might confuse second/foreign language learners. ... Seventy-three percent of students reporting Japanese definition of "tool" were correct. Nine percent of students, however, reported 背 が 高い (sega takai) which means “tall.” It is reasonable to assume that this type of error may be due to students thinking in katakana and therefore mis-decoding the word. Rather than translating "tool" into Japanese, students may simply be seeking phonically similar Japanese words then providing those words' Japanese meaning. A student may read "tool" and then think トール (tooru) which is the loanword for "tall."

Another potential source of katakana synform errors can arise from the difference in the vowels found in the two languages, as illustrated with "tool," above.

\section{Google}

Translate

\begin{tabular}{|c|c|c|c|c|c|c|c|c|c|c|}
\hline Japanese & English & Spanish & Detect language & - & $\Rightarrow$ & English & Japanese & Spanish & - & Translate \\
\hline $\begin{array}{l}\text { folk } \\
\text { fork }\end{array}$ & & & & & $x$ & $\begin{array}{l}\text { フォ } \\
\text { フ }\end{array}$ & $\begin{array}{l}-ク \\
-ク\end{array}$ & & & \\
\hline 4) $\square=$ & & & & & $9 / 5000$ & 哂回 & 4) $<$ & & & \\
\hline
\end{tabular}

Figure 1. Google Translate translation of "folk" and "fork." 
Half of the English vowels listed in Bada (2001) are not found in the Japanese syllabary. Accordingly, katakana users can "be predicted to replace /æ/ with either /e/, /e:/ or /a/; / / with a rather open /a/; and /D/ and / /:/ with /o/ or /o:/, these sounds being the closest counterparts of the vowels in Japanese" (Bada, 2001, pp. 4-5). This difference in vowels, when it causes confusion between otherwise similar English words, can be seen as corresponding roughly to categories 6, 7, and 10 in Laufer's taxonomy, which deal with different types of vowel confusion.

\section{Aim}

To the best of our knowledge, this katakana consonant synform confusion has yet to be identified and studied. Accordingly, the purpose of this study is to answer the following research question:

Do words liable to katakana consonant pairing confusion have more translation errors than non-katakana consonant pairing items of similar frequencies for high-beginner to mid-intermediate Japanese university students studying English?

\section{Method}

\subsection{Participants}

Participants were first-year and second-year $(N=235)$ Japanese university students from six separate compulsory language classes. Students (126 females and 109 males) were enrolled in a variety of programs. English proficiency levels were judged to be high-beginner to low-intermediate.

\subsection{Testing Instrument and Procedure}

A decontextualized L2 to L1 (English to Japanese) passive recall translation test of 60 individual words was created. A list of 30 possible katakana synform word pairs was created, based on the following consonant pairs: f-h; 1-r; v-b (in either initial, middle, or final syllabic position); and m-n (in syllabic final position)." For example, paired words included: appeal-appear, hill-fill, van-ban, and sum-sun. Using the JACET 8000 Level Marker 2015 (JACET Basic Words Revision Committee, 2016; hereinafter J8000), the frequency level for each of the 60 words was determined (from $1 \mathrm{~K}$ for the 1,000 most frequent English words, through $8 \mathrm{~K}$ being words from the 7,001 to 8,000 band). With only one exception, the less frequent word of each pair was tested. With the pair grass-glass, grass appears in the $1 \mathrm{~K}$ band of the $\mathrm{J} 8000$ while glass is listed as a $2 \mathrm{~K}$ word. This is opposite to Lextutor's VocabProfiler's ranking of $1 \mathrm{~K}$ and $2 \mathrm{~K}$ for glass and grass, respectively (Cobb, 2002; Heatley, Nation, \& Coxhead, 2002).

A similar list of 30 non-synform words was also created. Using the older version of the JACET 8000 (JACET Basic Words Revision Committee, 2003), which ranks the top 8,000 words from 1 to 8,000 for the Japanese context, non-synform 
words which were ranked very closely to each of the 30 synform words were selected. These non-synform words were only slightly more frequent on average than the 30 synform words, with mean frequency levels of 4.33 and 4.5 , respectively, in the new J8000 lists. All 60 items were placed in random order in the translation test.

Subsequently, one reviewer of this article suggested that the m-n in syllabic final position words should not cause any more confusion than non-katakana synform words. Accordingly, the synform items warn, sum, lime, and mime and their matching non-synform items excellent, shade, sprinkle, and intricate have been removed from the item list, leaving 52 tested words (26 synforms and 26 non-synforms; see Appendix B for a listing of all 52 words).

All testing was done during the class time and averaged about 15 minutes. Test-takers were asked to supply two different meanings in Japanese, if possible, for each of the tested items. This was done to avoid the possibility of students writing only one answer (as naturally occurs when only one space is provided) that happens to be incorrect while still knowing a different correct answer. It would also hopefully avoid the ambiguity caused by students who supply only one answer in katakana (e.g., フォーク).

At the end of each testing session, the translation tests were collected and subsequently graded by one of the authors. Prior to grading, 24 test forms $(10 \%)$ were randomly selected, copied, and graded by a different native Japanese teacher of English. Inter-rater reliability, as estimated by Cohen's kappa was 0.82, which is considered as strong (Pallant, 2007). All translations for each tested item were then back-translated into English, and the errors were entered into a spreadsheet for analysis. As we were interested only in common translation errors made on an L2 to L1 translation test, only errors repeated by 24 or more participants $(10 \%)$ were examined.

Despite the instruction to provide two responses, there were only 727 second response of a possible 12,220 (235 students $\times 60$ words $)$ - only $5.9 \%$. The reasons for this low second response may include the lack of knowledge or laziness by the test takers. In the event that both answers were correct, the word was originally scored " 2 " (both correct), which was later changed to "1" (correct) for the following analysis.

\section{Results}

The mean score on this translation test was 24.49 of the 52 tested items $(47 \%$; see Table 1), with scores ranging from 10 to 41 of the 52 tested items. For the 26 katakana synform words, the mean was $10.34(40 \%)$, considerably lower than the

Table 1. Descriptive Statistics for the Translation Test

\begin{tabular}{lcccc}
\hline Tr. items & Mean (\%) & SD & Low & High \\
\hline Full 52 items & $24.49(47.1 \%)$ & 5.39 & 10 & 41 \\
26 katakana synforms & $10.34(39.8 \%)$ & 3.31 & 3 & 22 \\
26 regular words & $14.16(54.5 \%)$ & 2.73 & 6 & 22 \\
\hline
\end{tabular}

Note: $n=235 ; k=52 ; \operatorname{Tr}$, translation test; SD, standard deviation.

Vocabulary Learning and Instruction, 9 (1), 62-72. 
Table 2. Common Translation Errors: 30 Katakana Synform Items

\begin{tabular}{llc}
\hline Katakana synform words & Mistranslation & Instances \\
\hline flesh & fresh & 130 \\
fright & flight & 107 \\
rip & lip & 104 \\
dairy & daily & 93 \\
& diary & 82 \\
clown & crown & 76 \\
load & road & 72 \\
& lord & 24 \\
van & ban & 61 \\
brow & blow & 56 \\
grass & glass & 52 \\
collect & correct & 41 \\
fork & folk & 35 \\
lush & rush & 32 \\
appeal & appear & 28 \\
row & raw & 24 \\
Total mistranslations & & 1,017 \\
\hline
\end{tabular}

Table 3. Common Translation Errors: 30 Regular Word Items

\begin{tabular}{llc}
\hline Regular words & Mistranslation & Instances \\
\hline machinery & mechanical & 84 \\
secretion & secret & 43 \\
Total mistranslations & & 127 \\
\hline
\end{tabular}

regular word mean of 14.16 of those 26 items (55\%). A paired $t$-test confirmed the statistical significance of the difference $(t(234)=20.9, p<0.0001)$. The effect size was 1.26 , which according to Cohen (1988) is large.

Many of the katakana synform word errors were classified as common translation errors, which, following Authors (2016), are defined as words with the exact same translation error being repeated by at least $24(10 \%)$ of the 235 test-takers. As shown in Table 2, 14 of the 26 katakana synform words elicited common translation errors. The total of 1,017 mistranslations accounted for $45 \%$ of the total number of incorrect answers (including blanks) for these 14 items. Table 3 shows that only two of the 26 regular words led to common translation errors (machinery and secretion). These 127 mistranslations accounted for $31 \%$ of the total incorrect answers (including blanks) for these two items.

\section{Discussion}

According to Daulton (1996), Japanese teachers of English at the junior high school level often resort to using katakana to explain English pronunciation. One reason for this may be that those teachers lack confidence with their English 
pronunciation abilities. Japanese learners of English often "transliterate long passages into katakana, typically scratching notes above the English in textbooks ..." (Daulton, 2008, p. 63). This reliance on katakana likely continues well into university. When older students encounter unfamiliar words in a text, they may resort to decoding those words using katakana in their search for meaning. If they encounter a low-frequency word like "van", for example, they may mentally transcribe it as “バン” and then confuse it with the other member of the /v/-/b/ katakana pairing, and accept it as the more familiar word "ban." It is easy to imagine that mis-readings caused by such phonetic confusion could easily lead to a lack of comprehension by the learner. The English textbooks presently used by junior high school students in Kitakyushu, Fukuoka, New Horizon English Course 1, 2, 3 (New Horizon, 2015), continues to rely on katakana when introducing new English vocabulary.

\section{Conclusion}

The present study has focused on common katakana synform errors made by Japanese university students $(n=235)$ when translating decontextualized English words (from all levels of the J8000 frequency list) into their native language. Of the 52 tested items, 50\% were katakana synform words, the remaining 50\% (26 words) were regular (non-synform) words selected from the same J8000 frequency levels. The results show that the 26 katakana synform words had significantly fewer correct translations $(40 \%)$ than the 30 regular words (55\%). To answer the aforementioned research question, these results suggest that katakana consonant pairing triggers katakana consonant synform errors for high-beginner to mid-intermediate Japanese university students studying English.

These results have implications for English language classrooms. Teachers should consider scanning assigned readings and/or vocabulary lists for possible lower frequency members of katakana consonant pairs. Japanese university students may also benefit from pronunciation practice with ///-/r/ and /v/-/b/ pair distinction. These results also have implications for vocabulary assessment. In testing lexical knowledge, researchers should be wary of the lower frequency members of katakana consonant pairs for decontextualized English to Japanese (L2 to L1) translation tests, and more importantly for yes-no checklists. Future research should try to discover whether similar katakana consonant synform errors would be made if the tested items were given some context (e.g., in a paragraph). This could be done by giving students a paragraph to read along with a translation test of some of the words (synform and non-synform) contained therein. This should be done after first giving a decontextualized translation test of the same items, to answer the question: Does context reduce katakana consonant synform errors?

\section{References}

Bada, E. (2001). Native language influence on the production of English sounds by Japanese learners. The Reading Matrix, 1(2). Retrieved from http://www. readingmatrix.com/articles/bada/article.pdf 
Cobb, T. (2002). Web Vocabprofile. Retrieved from http://www.lextutor.ca/vp/. (an adaptation of Heatley, Nation \& Coxhead's (2002) Range).

Cohen, J. (1988). Statistical power analysis for the behavioral sciences (2nd edn.). Hillsdale, NJ: Lawrence Erlbaum.

Daulton, F. E. (1996). Katakana English and the teaching of pronunciation. Journal of Nanzan Junior College, 24, 43-54.

Daulton, F. E. (1998). Loanword cognates and the acquisition of English vocabulary. The Language Teacher, 22(1), 17-25.

Daulton, F. (2008). Japan's built-in lexicon of English-based loanwords. Clevedon, UK: Multilingual Matters Ltd.

Gu, Y., \& Leung, C. (2002). Error patterns of vocabulary recognition for EFL learners in Beijing and Hong Kong. Asian Journal of English Language Teaching, 12, 121-141.

Heatley, A., Nation, I. S. P., \& Coxhead, A. (2002). RANGE and FREQUENCY programs. Retrieved from http://www.victoria.ac.nz/lals/staff/paul-nation.aspx

Kocic, A. (2008). The problem of synforms (Similar lexical forms). Linguistics and Literature, 6(1) 51-59.

JACET Basic Words Revision Committee (Eds.). (2003). JACET list of 8000 basic words (JACET8000). Tokyo, Japan: JACET.

JACET Basic Words Revision Committee (Eds.). (2016). The new JACET list of 8000 basic words. Tokyo, Japan: Kiriharashoten. Retrieved from http://mochvocab.sakura.ne.jp/cgi-bin/J8LevelMarker/j81m.cgi

Janjua, N. (2010). A tool for minimizing L1 interference in pronunciation in the Japanese EFL classroom. In A. M. Stoke (Ed.), JALT2009 conference proceedings, 381-391. Tokyo, Japan: JALT.

Laufer, B. (1988). The concept of "synforms" (similar lexical forms) in vocabulary acquisition. Language and Education, 2(2), 113-132. doi: 10.1080/09500788809541228

Laufer, B. (1997). What's in a word that makes it hard or easy? Intralexical factors affecting the difficulty of vocabulary acquisition. In: M. McCarthy \& N. Schmitt (Eds.), Vocabulary description, acquisition and pedagogy (pp. 140-155). Cambridge University Press.

Laufer, B., Meara, P., \& Nation, I. S. P. (2005). Ten best ideas for teaching vocabulary. The Language Teacher, 29(7), 3-6.

Nakao, K. (2013). What does knowing a loanword mean for Japanese students? VERB, 2(2), 13-14.

New Horizon. (2015). New Horizon English Course, 1, 2, \& 3. Tokyo: Shoseki.

Nural, S. (2014). Approaching synforms (similar lexical forms) in an EAP context. Theory and Practice in Language Studies, 4(9), 1753-1762. doi: 10.4304/ tpls.4.9.1753-1762

Pallant, J. (2007). SPSS survival manual: A step by step guide to data analysis using SPSS (3rd edn.). Crow's Nest, Australia: Allen \& Unwin. 
Stubbe, R., \& Cochrane, Y. (2016). Common errors on an L2 to L1 translation test.Vocab@Tokyo Conference Handbook. Tokyo, Japan: JALT Vocab SIG.

Uchida, E. (2007). Oral and written identification of L2 loanword cognates by initial Japanese learners of English. The Language Teacher, 31(9), 19-22. 


\section{Appendix}

Appendix A. Laufer's 1988 List of Synform Errors

\begin{tabular}{|c|c|c|}
\hline Category & Explanation & Example \\
\hline 1 & $\begin{array}{l}\text { Synforms which have the same root, productive in present } \\
\text { day English, but are different in suffix. }\end{array}$ & interested/interesting \\
\hline 2 & $\begin{array}{l}\text { Synforms identical in root, which is not productive in } \\
\text { present day English, and are different in their suffix. }\end{array}$ & $\begin{array}{l}\text { experiment/ } \\
\text { experience }\end{array}$ \\
\hline 3 & $\begin{array}{l}\text { Synforms which differ from each other in a suffix present } \\
\text { in one of the synforms but absent in the other. }\end{array}$ & historic/historical \\
\hline 4 & $\begin{array}{l}\text { Synforms identical in root, which is not productive in } \\
\text { present day English, and are different in prefixes. }\end{array}$ & $\begin{array}{l}\text { attribution/contribution/ } \\
\text { distribution }\end{array}$ \\
\hline 5 & $\begin{array}{l}\text { Synforms which differ from one another in prefix present } \\
\text { in one of the synforms but not in the other. }\end{array}$ & passion/compassion \\
\hline 6 & $\begin{array}{l}\text { Synforms which differ from one another in one vowel or } \\
\text { diphthong. }\end{array}$ & affect/effect \\
\hline 7 & $\begin{array}{l}\text { Synforms which differ in one vowel which is present in one } \\
\text { synform but absent in the other. }\end{array}$ & live/alive \\
\hline 8 & Synforms which differ from one another in one consonant. & extend/extent \\
\hline 9 & $\begin{array}{l}\text { Synforms which differ from each other in one additional } \\
\text { consonant (a consonant present in one synform but } \\
\text { absent in the other. }\end{array}$ & phase/phrase \\
\hline 10 & Synforms identical in consonants but different in vowels. & base/bias \\
\hline
\end{tabular}

Source: Laufer (1988, pp. 125-129); see that article for greater details. 
Appendix B. Items Used in this Study

\begin{tabular}{|c|c|c|c|}
\hline \multicolumn{2}{|c|}{26 katakana consonant synform words } & \multicolumn{2}{|c|}{26 regular words } \\
\hline Item & J8000 frequency & Item & J8000 frequency \\
\hline fear (hear) & 602 & local & 603 \\
\hline hill (fill) & 976 & quiet & 977 \\
\hline collect (correct) & 1,056 & generation & 1,057 \\
\hline appeal (appear) & 1,129 & onto & 1,130 \\
\hline fair (hair) & 1,168 & nurse & 1,169 \\
\hline grass (glass) & 1,310 & organization & 1,311 \\
\hline row (low) & 1,411 & ill & 1,412 \\
\hline flesh (fresh) & 2,161 & user & 2,162 \\
\hline load (road) & 2,180 & pig & 2,181 \\
\hline raw (law) & 2,188 & bitter & 2,187 \\
\hline tiled (tired) & 2,767 & machinery & 2,655 \\
\hline fork (folk) & 2,918 & fighter & 2,768 \\
\hline hence (fence) & 3,165 & eyebrow & 2,917 \\
\hline rent (lent) & 3,285 & maximum & 3,164 \\
\hline clash (crash) & 3,887 & qualify & 3,286 \\
\hline scare (scale) & 4,104 & striker & 3,888 \\
\hline rip (lip) & 4,410 & grief & 4,105 \\
\hline brow (blow) & 4,481 & intake & 4,411 \\
\hline dairy (daily) & 4,880 & exile & 4,482 \\
\hline rot (lot) & 5,225 & reservoir & 4,878 \\
\hline hound (found) & 6,288 & secretion & 5,226 \\
\hline van (ban) & 6,545 & arctic & 6,494 \\
\hline clown (crown) & 6,865 & lucrative & 6,866 \\
\hline fright (flight) & 7,366 & infancy & 7,367 \\
\hline lush (rush) & 7,609 & awesome & 7,610 \\
\hline vest (best) & 7,644 & fragrance & 7,645 \\
\hline Mean J8000 & 3750.3 & Mean J8000 & 3621.2 \\
\hline
\end{tabular}

Note: Words in parentheses are expected synform errors. 